\title{
Effects of halothane sensitivity on growth and body composition traits in pigs
}

\author{
Y. HOUIX, P. SELLIER *, G. MONIN ** \\ I.T.P., Station de Sélection porcine, 27, rue de Bapaume, Le Transloy, \\ 62450 Papaume \\ *I.N.R.A., Station de Génétique quantitative et appliquée, 78350 Jouy-en-Josas \\ *: I.N.R.A., Station de Recherches sur la Viande, Thei.r, 63122 Ceyrat \\ France
}

\begin{abstract}
A 5-minute halothane test was carried out at about 80 days of age in 1178 females entering the progeny-testing station at Le Transloy in 1979-1981 and issued from breeding farms of four breeds : Large White (LW), French Landrace (FL), Belgian Landrace (BL), and Pietrain (PP). Among $412 \mathrm{LW}, 264 \mathrm{FL}, 450 \mathrm{BL}$ and $52 \mathrm{PP}$ pigs, incidence of positive halothane reaction was $0,19.3,83.8$ and $82.7 \mathrm{p}$. 100, respectively. Mortality due to stress syndrome (excluding mortality immediately following positive reaction at halothane testing but including transport losses) was significantly higher in halothane positive (HP) than in halothane negative (HN) pigs : 4.76 vs 0.14 p. 100 . No within-hreed difference between $\mathrm{HP}$ and $\mathrm{HN}$ pigs was found in average daily gain from 35 to $100 \mathrm{~kg}$ liveweight (on ad libitum feeding). In both FL and BL, HP pigs had shorter carcass length (CL) than $\mathrm{HN}$ pigs from the same breed, and showed significant advantage in killing out percentage (KOP), backfat thickness (BT) and estimated carcass lean content (ECLC). However, a significant interaction between Landrace strain and type of halothane reaction was found in KOP, $\mathrm{CL}$ and ECLC, with the difference between $\mathrm{HP}$ and $\mathrm{HN}$ pigs being larger in FL than in BL $(3.3 v s .9 \mathrm{~kg}$ in estimated lean tissue weight per pig). The latter results are interpreted as indicating that the gene effects at the halothane sensitivity locus are approximately additive with respect to be main body composition traits : the proportion of heterozygotes among HN pigs is indeed expected to be higher in BL than in FL.
\end{abstract}

\section{Comparison of the genetic levels of breeding and commercial farms in the Large White pig breed}

\author{
J.P. RUNAVOT, P. SELLIER * \\ I.T.P., Région Ouest, La Motte-au-Vicomte, B.P. 3, 35650 Le Rheu \\ *I.N.R.A., Station de Génétique quantitative et appliquée, 78350 Jouy-en-Josas \\ France
}

Purebred Large White pigs from either 54 breeding farms (selcction : LWS) or 54 commercial farms (production : LWP) were compared in central progeny-testing stations with respect to growth and carcass traits. A significant superiority of LWS pigs $(n=193)$ as compared to LWP pigs $(\mathrm{n}=230)$ was found in most growth and body composition traits : 844 vs $826 \mathrm{~g}$ in average daily gain from 35 to $100 \mathrm{~kg}(\mathbf{P}<0.10), 2,98$ vs 3.06 feed $/ \mathrm{kg}$ gain in food conversion ratio in the same period of time $(\mathrm{P}<0.01), 73.8$ vs 73.5 p. 100 in killing out percentage $(P<0.05), 21.1$ vs $21.9 \mathrm{~mm}$ in average backfat thickness $(\mathrm{P}<0.10)$, 52.3 vs 51.2 and 26.3 vs 27.6 in estimated carcass lean meat and fat percentages $(P<0.01)$, respectively. However, a disadvantage of LWS relative to LWP pigs $(P<0.05)$ was found in a subjective score of meat quality and a meat quality index combining ultimate $\mathrm{pH}$, colour and water holding capacity measurements. An attempt was made to evaluate the expected difference in genetic level between the LWS and LWP populations, i.e. the improvement lag. The expected genetic lag of LWP relative to LWS was approximately 1.68 generation or 2.77 years of selection. Annual genetic trends in the Large White breeding herds were determined in comparing observed and expected genetic lags of LWP as compared to LWS : annual genetic gain in overall economic value per pig fattened from 25 to $100 \mathrm{~kg}$ was around 7 francs on the short period considered. However, this figure does not take account of the unfavourable genetic trends observed in meat quality traits. 